\title{
Infection of the Norway lobster Nephrops norvegicus by a Hematodinium-like species of dinoflagellate on the west coast of Scotland
}

\author{
R. H. Field ${ }^{1}$, C. J. Chapman ${ }^{2}$, A. C. Taylor ${ }^{1}$, D. M. Neil ${ }^{1}$, K. Vickerman ${ }^{1}$ \\ 'Zoology Department, University of Glasgow, Glasgow G12 8QQ, Scotland, UK \\ ${ }^{2}$ Scottish Office Agriculture and Fisheries Department (SOAFD) Marine Laboratory, PO Box 101, Victoria Road, Torry, \\ Aberdeen AB9 8DB, Scotland, UK
}

\begin{abstract}
Nephrops norvegicus (L.) from fishing grounds on the west coast of Scotland has been found to harbour infection by a species of parasitic dinoflagellate. Chromosome morphology and ultrastructural features suggest that the parasite is a member of the botanical order Syndiniales, possibly related to Hematodinium perezi Chatton \& Poisson 1931. Cells invading the haemal spaces, however, show no signs of flagella. Mode of transmission is not yet known, and a flagellate spore stage has not been identified. Infection appears to be fatal to its host, the main cause of death possibly being disruption of gas transport and tissue anoxia caused by the proliferation of large numbers of dinoflagellate cells in the haemolymph. Severe infection has an adverse effect on meat quality that has provoked comment from fisherman and processors. Affected lobsters have been found at all west coast sites surveyed, with peak infection rates reaching $70 \%$ of trawled samples. Infection occurrence shows marked seasonality coincident with the annual moult period of $N$. norvegicus. An increased prevalence of infection has been observed recently in some areas.
\end{abstract}

\section{INTRODUCTION}

Nephrops norvegicus (L.) is a commercially important species in the United Kingdom, supporting a large trawl fishery off the west coast of Scotland, currently valued at $£ 20$ million per annum at first sale prices. During the course of routine investigations into the biology of $N$. norvegicus in the Firth of Clyde during the early 1980's the occurrence was noted of a low prevalence of lobsters with an abnormal dull orange colouration. Such individuals were observed to be in a moribund state, with 'watery' muscles, low haemolymph pressure and milky-white body fluids, apparently associated with increased numbers of cells. Initially, this condition was thought to be associated with the moult cycle of $N$. norvegicus, as it coincided with the annual moult period of Clyde populations, between February and May. By 1987, the poor quality of the tissues and their 'watery' appearance had evoked comment from fishermen and processors. Consequently, a sampling programme was initiated by the Scottish Office Agriculture and Fisheries Department (SOAFD) to define more precisely the seasonality of occurrence and geographical prevalence of this condition around the west coast of Scotland. An investigation was launched concurrently into the physiology and pathology of affected lobsters.

Examination of affected lobsters led to the discovery of non-motile, protistan parasites filling the haemal spaces. Evidence is presented here that these parasites are dinoflagellates of the order Syndiniales, and resemble in particular Hematodinium perezi Chatton \& Poisson, 1931, known to infect other species of decapod Crustacea. Until recently, although abundant in the marine habitat and known to be destructive to their hosts, parasitic dinoflagellates had been studied by relatively few workers. Chatton and other workers (see Chatton 1952) identified several genera of dinoflagellates infecting Crustacea and other invertebrates. Chatton \& Poisson (1931) found $H$. perezi in the haemolymph of Carcinus maenas and Liocarcinus depurator in European waters. In more recent years Hematodinium sp. has been found in Callinectes sapidus (Newman \& Johnson 1975), in 2 species of Cancer (C. irroratus and C. borealis) and in the portunid crab Ovalipes ocellatus (Maclean \& Ruddell 
Table 1. Nephrops norvegicus. Variation of total haemolymph cell counts in relation to degree of severity of infection, assessed by pleopod staging on an arbitrary scale from I to IV (0 = apparently uninfected)

\begin{tabular}{|c|c|c|c|c|}
\hline \multirow[t]{2}{*}{$\begin{array}{l}\text { Pleopod } \\
\text { stage }\end{array}$} & \multirow[t]{2}{*}{ Description } & \multirow[t]{2}{*}{$\begin{array}{l}\text { No. of } \\
\text { lobsters }\end{array}$} & \multicolumn{2}{|c|}{$\begin{array}{l}\text { Haemolymph cell count } \\
\left.\qquad \times 10^{4} \mathrm{~mm}^{-3}\right)\end{array}$} \\
\hline & & & Mean & $\mathrm{SD}$ \\
\hline 0 & $\begin{array}{l}\text { A few cells visible, no aggregation, } \\
\text { pleopod clear }\end{array}$ & 11 & 1.348 & 0.563 \\
\hline I & $\begin{array}{l}\text { Clumps of aggregated cells around } \\
\text { pleopod periphery }\end{array}$ & 12 & 1.346 & 0.932 \\
\hline II & $\begin{array}{l}\text { Cell aggregation continuous around } \\
\text { pleopod periphery }\end{array}$ & 12 & 2.017 & 1.337 \\
\hline III & $\begin{array}{l}\text { Layer of aggregated cells expanded } \\
\text { to more central areas of pleopod }\end{array}$ & 7 & 8.551 & $5.650^{\circ}$ \\
\hline IV & $\begin{array}{l}\text { Pleopod interior almost totally obscured } \\
\text { by masses of aggregated cells }\end{array}$ & 4 & 3.331 & 1.171 \\
\hline
\end{tabular}

1978). A prominent feature of these infections has been the low prevalence of occurrence, below $5 \%$. In Callinectes sapidus occurring off the Florida, USA, coast, however, infections reached a peak prevalence of $30 \%$ (Newman \& Johnson 1975). In the past $5 \mathrm{yr}$, however, seasonal Hematodinium sp. infections of Necora (= Liocarcinus) puber and Cancer pagurus have been reported around the north and west coasts of France associated with winter crab mortalities (Wilhelm \& Boulo 1988, Latrouite et al. 1988). Peak prevalences in $N$. puber were observed to be as high as $87 \%$ at 1 site in early 1987, and a significant effect on stocks was postulated (Wilhelm \& Boulo 1988). In addition, infections of commercially fished populations of Tanner crabs (Chionoecetes bairdi and, to a lesser extent, $C$. opilio) in the Bering Sea and southeast Alaskan waters with a Hematodinium-like dinoflagellate have been reported, with peak prevalences of nearly $100 \%$ (Meyers et al. 1987, Meyers 1990, Meyers et al. 1990, Eaton et al, 1991).

This report presents preliminary gross and microscopical descriptions of the disease in Nephrops norvegicus and describes the morphology of the putative causative agent in support of its designation as a parasitic dinoflagellate. In addition, information is given on the prevalence and distribution of the disease in $N$. norvegicus populations at various sites on the west coast of Scotland, as well as preliminary estimates of host mortality.

\section{MATERIALS AND METHODS}

Laboratory specimens. Nephrops norvegicus used in laboratory investigations were obtained by trawling during the course of prevalence and distribution inves- tigations, or were caught by the use of lobster pots (creels) on grounds close to the Isle of Cumbrae, Firth of Clyde. Lobsters were transported in oxygenated tanks and subsequently maintained in aquaria in well aerated running seawater at the Zoology Department, University of Glasgow. Seawater temperature ranged between 10 and $13^{\circ} \mathrm{C}$ and salinity between 33 and $34 \%$. Lobsters were fed ad libitum on squid and mussel flesh.

Diagnosis. In the advanced stages of infection, affected lobsters were easily recognised by the dull orange colouration of the body and appendages, and milky-white haemolymph, clearly visible through the translucent cuticle of the ventral abdomen. However, mild infections could not be reliably identified by this method alone. The condition was most easily and accurately diagnosed by microscopic examination of the pleopods where, under transmitted light, dense aggregations of the parasite appeared as darkened areas. This method was found to be effective and consistent in identifying even slight infection, and was also useful in providing a measure of severity of the condition. Severity was measured on a scale from I to IV (0 for uninfected animals), based on the degree of cell aggregation visible in the pleopod (Table 1).

Haemolymph investigations. The milky-white, turbid appearance of the haemolymph of affected lobsters suggested an increase in the number of haemocytes, and was initially thought to represent some form of proliferative disorder. This prompted an examination of haemocyte numbers. Haemolymph samples of $500 \mu \mathrm{l}$ were collected from the base of a fifth pereiopod using $1 \mathrm{ml}$ disposable syringes containing an equal volume of diluting fluid. Samples were diluted and the cells were counted by the method of Stewart et al. (1967). In addition, smears were made using undiluted 
haemolymph from another group of lobsters, and stained with Leishman's stain. Examination of such smears indicated the presence of varying numbers of protistan cells, and also yielded estimates of the relative proportions of host haemocytes and parasite cells present. Both uninfected and infected lobsters of all degrees of severity were examined, but only individuals in intermoult were used, as determined by the pleopod moult staging technique of Aiken (1980).

Haemolymph of healthy Nephrops norvegicus is a translucent blue, imparted by the presence of the oxygenated form of the copper-based respiratory pigment haemocyanin. This colour was not evident in the haemolymph of infected individuals, and consequently an analysis of the oxygen-carrying capacity and copper concentrations of the haemolymph of these lobsters was undertaken. Following dilution with deionised water the copper concentration of the haemolymph was determined using an atomic absorption spectrophotometer (Philips PU9200) calibrated with an appropriate range of copper standards. The haemocyanin oxygen-carrying capacity of the haemolymph was determined using the method of Tucker (1967) as modified by Bridges et al. (1979).

Histopathology. Two male Nephrops norvegicus, exhibiting severe infection (Stage III by pleopod examination) were dissected to provide samples of the major organs. Two additional individuals ( 1 male and 1 female), both confirmed to be healthy by pleopod examination, provided samples of uninfected tissues from the same organs. All specimens were in intermoult, and were caught by trawling during routine sampling in the Clyde. The organs removed were: hepatopancreas, antennal gland, gastric mill, midgut, abdominal muscle, haemopoietic tissue, heart, gills and pleopod. Upon removal, tissues were fixed in Helly's mercuric chloride fixative (Johnson 1980) and then paraffin-embedded. Thin sections $(6 \mu \mathrm{m})$ were treated with Lugol's iodine solution to remove mercury, and stained with haematoxylin and eosin (H \& E) (Johnson 1980).

Electron microscopy. Haemolymph was taken from 1 severely infected male (Stage III) and 1 healthy male Nephrops norvegicus for examination of the cells contained therein by electron microscopy. To minimise sampling artifacts by mechanical stresses and clotting, haemolymph was allowed to flow from a cut walking leg directly into fixative (2\% paraformaldehyde, $1 \%$ glutaraldehyde, $4 \%$ sucrose in $0.1 \mathrm{M}$ phosphate buffer). Cells for examination by transmission electron microscopy (TEM) were rinsed twice in chilled phosphate buffer (0.1 $\mathrm{M} \mathrm{PO}_{4}, 8 \%$ sucrose), post fixed in $1 \%$ $\mathrm{OsO}_{4}$ in phosphate buffer and pelleted by centrifugation. Pellets were stained with $0.5 \%$ uranyl acetate, dehydrated through an alcohol series and embedded in
Araldite. Thin sections ( 60 to $70 \mathrm{~nm}$ ) were stained with uranyl acetate and lead citrate and examined using a Philips 301 TEM. Cells for scanning electron microscope (SEM) examination were dehydrated through an acetone series, resuspended and filtered through $0.2 \mu \mathrm{m}$ microfilters after uranyl acetate staining. Cells retained on filters were then critical point dried, coated with gold and examined using a Philips 500 SEM.

Estimates of host mortality. During 2 sampling cruises aboard the RV 'Aora' in the Clyde Sea in March and April 1991, a total of 202 undamaged Nephrops norvegicus were collected by trawling. These lobsters, which comprised both healthy and infected individuals, were maintained under laboratory conditions in order to obtain estimates of mortality due to infection. Immediately after capture, records were made of the carapace length, moult stage and sex of each individual together with its state and severity of infection. For the latter measurements only the tip of a pleopod was removed from each lobster, in order to minimise stress. Specimens were then assigned a numbered claw tag for individual identification. After immobilising their chelipeds with elastic bands to prevent fighting, lobsters were maintained in running seawater tanks on board ship and later transferred to the aquarium in the Zoology Department, Glasgow University. The tanks were checked regularly and any dead lobsters were removed, their tag numbers, moult stages, state of infection and date of death recorded.

Prevalence and distribution. From May 1987 to May 1989 small mesh trawl (SOAFD Type BT 126D) samples were taken periodically during routine cruises aboard the RV 'Aora', at 3 locations in the Firth of Clyde. Locations were south of Ailsa Craig (mean depth $60 \mathrm{~m}$ ), north of Arran (mean depth $89 \mathrm{~m}$ ) and in the Cumbrae-Bute Channel (mean depth $77 \mathrm{~m}$ ) (Fig. 1; Sites 14,4 \& 1 respectively). The prevalence of infection (assessed by body colour only) was recorded in relation to size and sex of Nephrops norvegicus at these 3 sites.

In 1990, work was confined to the period MarchApril but, in addition to the Clyde, sampling was extended to other sites around the west coast of Scotland (Fig. 1, Table 2). Again, samples were taken using a small mesh trawl from the RV 'Aora', and bottom water samples were taken at each site for measurement of dissolved oxygen content, salinity and temperature. The prevalence and severity of infection were assessed at each site, by both colour and pleopod examination, in relation to sex, size and moult stage.

A similar sampling programme was undertaken during March and April 1991 at a range of sites in the Clyde and around the west coast of Scotland (Fig. 1, Table 3). Infection prevalence and severity, sex, size and moult stage data were recorded as in the 1990 survey. Additional trawl samples from the Clyde 


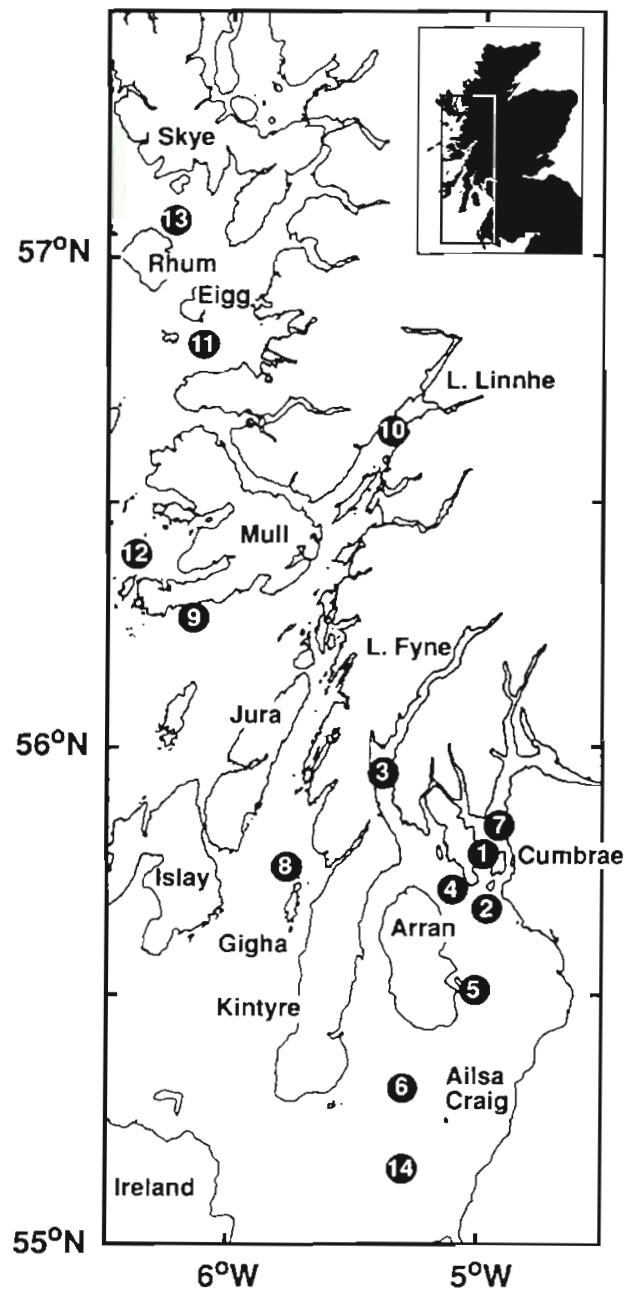

Fig. 1 West coast of Scotland. Sampling stations during cruises of RV 'Aora' between May 1987 and April 1991. Sites numbered as in the text and Tables 2 and 3 grounds close to the Isle of Cumbrae (Fig. 1; Site 2) were obtained on 2 May, 12 June, 3 July and 22 August. 1991.

\section{RESULTS}

\section{Description of the condition and parasite}

Gross appearance

Infected lobsters sustained varying degrees of lethargy, which seemed to worsen with increased severity of infection. Severely affected individuals were moribund and often had difficulty in walking or even supporting themselves. The milky-white appearance of the haemolymph appeared to be due mainly to the presence of increased total cell numbers (both host haemocytes and protistan cells), but also to quantities of suspended 'debris'. Examination of the cephalothoracic cavity showed that the internal organs were coated in thick 'creamy' deposits, similar in appearance to the haemolymph. The haemolymph also appeared reduced in volume and of increased viscosity. The haemopoietic tissue, the heart and pericardium were swollen and yellow with collected haemolymph. Other organs were shrunken, most strikingly the hepatopancreas, which also had a very obvious green colouration instead of the normal brown

Counts of total numbers of cells in the haemolymph (both host haemocytes and protistan cells) confirmed that the abnormal colouration of the haemolymph in severely affected lobsters was due to an increase in cell numbers (Table 1). These counts in mild infections (pleopod Stages I and II; $1.35 \times 10^{4} \pm 0.93 \times 10^{4}$ and $2.02 \times 10^{4} \pm 1.34 \times 10^{4}$ cells $\mathrm{mm}^{-3}$ respectively) were

Table 2. Nephrops norvegicus. Prevalence (\%) of infected lobsters in small mesh trawl samples during March-April 1990 in the Clyde and South Minch assessed by body colour and pleopods. Sampling sites are numbered as in Fig. 1. M: males; F: females; $M$ \& F: males and females combined; P: premoult; $I$ : intermoult

\begin{tabular}{|c|c|c|c|c|c|c|c|c|c|c|c|}
\hline \multirow[t]{2}{*}{ Area } & \multirow[t]{2}{*}{ Site no., description } & \multirow[t]{2}{*}{ Date } & \multirow{2}{*}{$\begin{array}{l}\text { No. of } \\
\text { lobsters }\end{array}$} & \multicolumn{3}{|c|}{ Body colour } & \multirow[b]{2}{*}{ M } & \multicolumn{3}{|c|}{ Pleopods } & \multirow[b]{2}{*}{ I } \\
\hline & & & & $M$ & $F$ & $M \& F$ & & $\mathrm{~F}$ & $M \& F$ & $P$ & \\
\hline \multirow[t]{4}{*}{ Clyde } & 1. Cumbrae Channel & 13-14 Mar & 154 & - & - & - & 56.6 & 68.0 & 58.4 & 66.7 & 605 \\
\hline & 2, 5 of Little Cumbrae & $14 \mathrm{Mar}$ & 136 & - & - & - & 81.7 & 93.8 & 84.6 & 82.4 & 84.7 \\
\hline & $4, \mathrm{~N}$ of Arran & $15 \mathrm{Mar}$ & 121 & - & - & - & 77.9 & 62.8 & 73.6 & 77.7 & 72.2 \\
\hline & Overall & & 411 & - & - & - & 70.5 & 75.0 & 71.5 & 77.1 & 75.8 \\
\hline \multirow[t]{5}{*}{ S Minch } & 9, Ross of Mull & $6 \mathrm{Apr}$ & 606 & 8.1 & 15.1 & 11.2 & 18.0 & 15.5 & 16.9 & 11.7 & 17.8 \\
\hline & 13. North Rhum & $7 \mathrm{Apr}$ & 582 & 8.4 & 10.5 & 9.3 & 11.4 & 12.1 & 11.7 & 9.8 & 12.1 \\
\hline & 10, Loch Linnhe & $8 \mathrm{Apr}$ & 558 & 10.4 & 11.9 & 11.1 & 14.2 & 20.9 & 17.5 & 17.5 & 17.5 \\
\hline & 8. NW Gigha & 9 Apr & 526 & 7.3 & 7.6 & 7.4 & 7.6 & 11.3 & 9.3 & 6.5 & 10.2 \\
\hline & Overall & & 2272 & 8.5 & 11.4 & 9.8 & 129 & 15.2 & 14.0 & 11.1 & 14.5 \\
\hline \multirow[t]{5}{*}{ Clyde } & 1. Cumbrae Channel & 10-13 Apr & & & & & & & & & \\
\hline & 2. 5 of Little Cumbrae & $10-13 \mathrm{Apr}$ & & & & & & & & & \\
\hline & 3, Loch Fyne & 10-13 Apr & 256 & 17.9 & 43.6 & 23.4 & 20.0 & 50.0 & 22.7 & - & - \\
\hline & $4, N$ of Arran & 10-13 Apr & & & & & & & & & \\
\hline & 5, Off Holy Isle & 10-13 Apr & & & & & & & & & \\
\hline
\end{tabular}


Table 3. Nephrops norvegicus. Prevalence (\%) of infected lobsters in trawl samples during March-August 1991 in the Clyde, Sound of Jura and South Minch assessed by body colour and pleopods. Sampling sites are numbered as in Fig. 1. M: males; F: females; $M$ \& F: males and females combined; P: premoult; I: intermoult

\begin{tabular}{|c|c|c|c|c|c|c|c|c|c|c|c|}
\hline \multirow[t]{2}{*}{ Area } & \multirow[t]{2}{*}{ Site no., description } & \multirow[t]{2}{*}{ Date } & \multirow{2}{*}{$\begin{array}{l}\text { No. of } \\
\text { lobsters }\end{array}$} & \multicolumn{3}{|c|}{ Body colour } & \multirow[b]{2}{*}{ M } & \multicolumn{3}{|c|}{ Pleopods } & \multirow[b]{2}{*}{ I } \\
\hline & & & & $M$ & $\mathrm{~F}$ & $M \& F$ & & $F$ & $M \& F$ & $P$ & \\
\hline \multirow[t]{6}{*}{ Clyde } & 1. Cumbrae Channel & $4 \mathrm{Mar}$ & 8 & 20.0 & 33.3 & 25.0 & - & - & - & - & - \\
\hline & 2, $\mathrm{S}$ of Little Cumbrae & $4 \mathrm{Mar}$ & 34 & 28.0 & 77.8 & 41.2 & - & - & - & - & - \\
\hline & 3, Loch Fyne & $5 \mathrm{Mar}$ & 31 & 30.4 & 50.0 & 35.5 & 27.3 & 62.5 & 36.7 & 20.0 & 40.0 \\
\hline & 4. North of Arran & $5 \operatorname{Mar}$ & 154 & 32.0 & 42.9 & 35.7 & 46.3 & 66.7 & 54.0 & - & - \\
\hline & 5, Off Holy Isle & $5 \mathrm{Mar}$ & 7 & 33.3 & - & 28.6 & - & - & - & - & - \\
\hline & Overall & & 234 & 30.8 & 46.2 & 35.9 & 42.7 & 66.2 & 51.1 & 20.0 & 40.0 \\
\hline Sound of & 8. NW Gigha & 6 Mar & 1339 & 18.2 & 16.7 & 17.8 & 18.5 & - & - & - & - \\
\hline Jura/ & 9. Ross of Mull & 7 Mar & 1724 & 20.5 & 18.5 & 19.9 & 24.9 & - & - & - & - \\
\hline \multirow[t]{4}{*}{ S Minch } & 10. Loch Linnhe & $8 \mathrm{Mar}$ & 1017 & 23.6 & 19.9 & 21.9 & 28.6 & - & - & - & - \\
\hline & 11, Maxwell Bank & $9 \mathrm{Mar}$ & 774 & 6.4 & 10.6 & 7.9 & 11.4 & 21.4 & 14.9 & 6.7 & 15.9 \\
\hline & 12, South of Staffa & $10 \mathrm{Mar}$ & 307 & 9.3 & 19.8 & 12.0 & 11.6 & 30.9 & 16.7 & 6.3 & 18.7 \\
\hline & Overall & & 5161 & 17.5 & 17.4 & 17.5 & 19.2 & 25.5 & 15.8 & 6.4 & 17.3 \\
\hline \multirow{7}{*}{ Clyde } & 6 , South of Arran & $11 \mathrm{Mar}$ & 267 & 8.7 & 18.9 & 12.4 & 14.5 & 28.1 & 19.4 & 5.2 & 22.7 \\
\hline & 5, Off Holy Isle & $11 \mathrm{Mar}$ & 43 & 5.9 & 22.2 & 9.3 & - & - & - & - & - \\
\hline & 2. S of Little Cumbrae & 11-13 Mar & 257 & 14.1 & 24.2 & 16.7 & 26.9 & 31.0 & 27.7 & - & - \\
\hline & 1. Cumbrae Channel & $12 \mathrm{Mar}$ & 750 & 14.1 & 20.8 & 16.8 & 22.2 & 33.0 & 26.5 & 17.0 & 28.7 \\
\hline & 4. North of Arran & $12 \mathrm{Mar}$ & 474 & 21.7 & 26.3 & 23.2 & 29.8 & 39.0 & 32.8 & 6.7 & 38.9 \\
\hline & 3. Loch Fyne & $13 \mathrm{Mar}$ & 127 & 8.4 & 28.1 & 13.4 & 13.7 & 42.4 & 21.1 & 4.0 & 25.2 \\
\hline & Overall & & 1918 & 14.7 & 22.5 & 17.4 & 21.8 & 33.7 & 25.6 & 9.0 & 29.0 \\
\hline \multirow[t]{4}{*}{ Clyde } & 1. Cumbrae Channel & $8 \mathrm{Apr}$ & 390 & 18.4 & 37.3 & 22.0 & 23.3 & 43.6 & 27.6 & 6.3 & 30.5 \\
\hline & 3. Loch Fyne & $9 \mathrm{Apr}$ & 137 & 18.0 & 42.3 & 22.6 & 18.8 & 63.0 & 27.3 & 16.7 & 29.6 \\
\hline & 7, Skelmorlie & $10 \mathrm{Apr}$ & 213 & 19.1 & 39.3 & 24.9 & - & - & - & - & - \\
\hline & Overall & & 740 & 18.5 & 38.9 & 23.0 & 21.7 & 50.0 & 27.5 & 10.7 & 30.2 \\
\hline \multirow[t]{5}{*}{ Clyde } & Sites around Isle & 2 May & 334 & 41.7 & 75.4 & 54.2 & - & - & - & - & - \\
\hline & of Cumbrae & 12 Jun & 230 & 40.7 & 64.2 & 50.4 & - & - & - & - & - \\
\hline & & $3 \mathrm{Jul}$ & - & - & - & 19.0 & - & - & - & - & - \\
\hline & & $3 \mathrm{Jul}$ & - & - & - & 21.0 & - & - & - & - & - \\
\hline & & 22 Aug & - & - & - & 1.0 & - & - & - & - & - \\
\hline
\end{tabular}

not significantly different from those of healthy individuals $\left(1.35 \times 10^{4} \pm 0.56 \times 10^{4}\right.$ cells $\left.\mathrm{mm}^{-3}\right)$, but Stage III infections were characterised by a significant, more than 4 -fold increase in total cell numbers above Stage II numbers (to $8.55 \times 10^{4} \pm 5.65 \times 10^{4}$ cells $\mathrm{mm}^{-3}$, $\mathrm{p}<0.005,1$-way ANOVA). Interestingly, more severe (Stage IV) infections showed a return to near normal numbers of circulating cells. Examination of stained haemolymph smears from other infected individuals (for which the degree of infection severity was not determined) showed that parasites comprised in some cases as little as $3 \%$, but in others as much as $89 \%$ of the total number of cells present (both haemocytes and parasites). This, in conjunction with the combined parasite/haemocyte cell counts, suggests that the increased numbers of all cells in the haemolymph of Stage III infected lobsters was due to increased numbers of protistan cells, and not haemocyte proliferation. Examination of such haemolymph smears also confirmed diagnoses of infection made by body colour and pleopod examination.

Copper concentrations in the haemolymph of in- fected lobsters were found to be significantly lower than those of healthy individuals $\left(0.61 \pm 0.29 \mathrm{mmol}^{-1}\right.$ compared with $0.94 \pm 0.34 \mathrm{mmol}^{-1}, \mathrm{p}<0.001$, $t$-test). The effects of infection on haemocyanin metabolism were further illustrated by the results of analyses of the haemocyanin oxygen-carrying capacity of the haemolymph of affected lobsters. These showed the carrying capacities of infected haemolymph to be significantly lower than those of healthy individuals $\left(0.25 \pm 0.21 \mathrm{mmol} \mathrm{l}^{-1}\right.$ compared with $0.44 \pm 0.17 \mathrm{mmol}$ $\mathrm{l}^{-1}, \mathrm{p}<0.001$, $t$-test).

\section{Microscopical appearance}

Examination of fresh, unfixed infected haemolymph by phase contrast microscopy revealed large numbers of non-motile protistan cells similar in size to host haemocytes (between 5 and $14 \mu \mathrm{m}$ in diameter) (Fig. 2). Host haemocytes were generally still present, but in much smaller numbers than the parasite. Whether or not host haemocyte numbers alone are changed abso- 


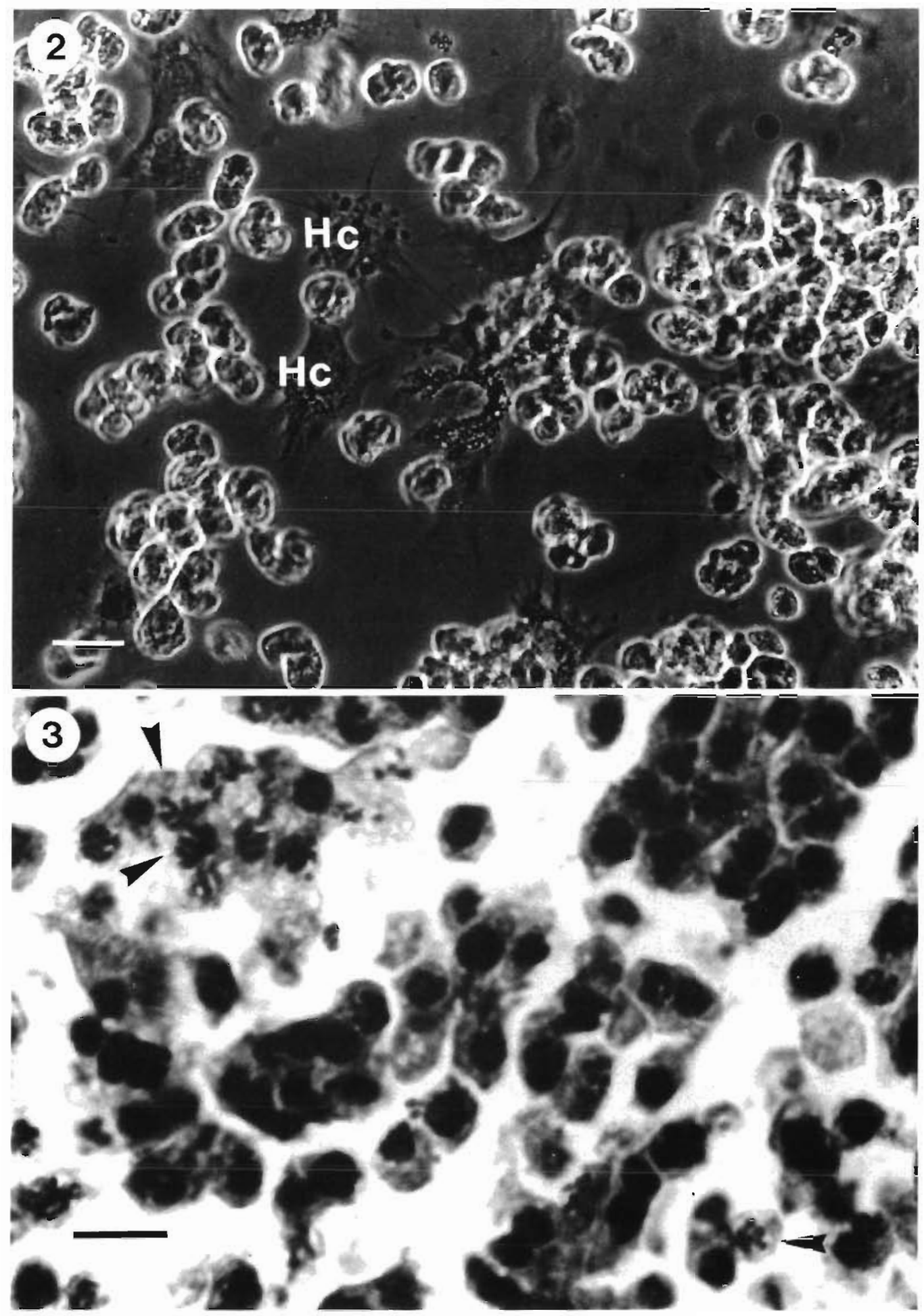

Figs. 2 \& 3. Nephrops norvegicus. Light micrographs of dinoflagellate cells in lobster Fig. 2. Uninucleate cells in fresh haemolymph. Note the apparently normal spreading of host haemocytes (Hc). Phase contrast. Scale bar $=10 \mu \mathrm{m}$; Fig. 3 . Parasite cells in the haemocoel. Note prominent chromosomes (arrows). Haematoxylin and Eosin. Scale bar $=10 \mu \mathrm{m}$

lutely in infected lobsters has not yet been determined. There was no evidence of impaired clotting ability (gelation of the fluid portion of the haemolymph), however, and haemocytes in fresh smears of infected haemolymph appeared to spread and aggregate normally (Fig. 2).

In histological sections, the parasite had infiltrated the haemal spaces of all the major organs, as well as the 


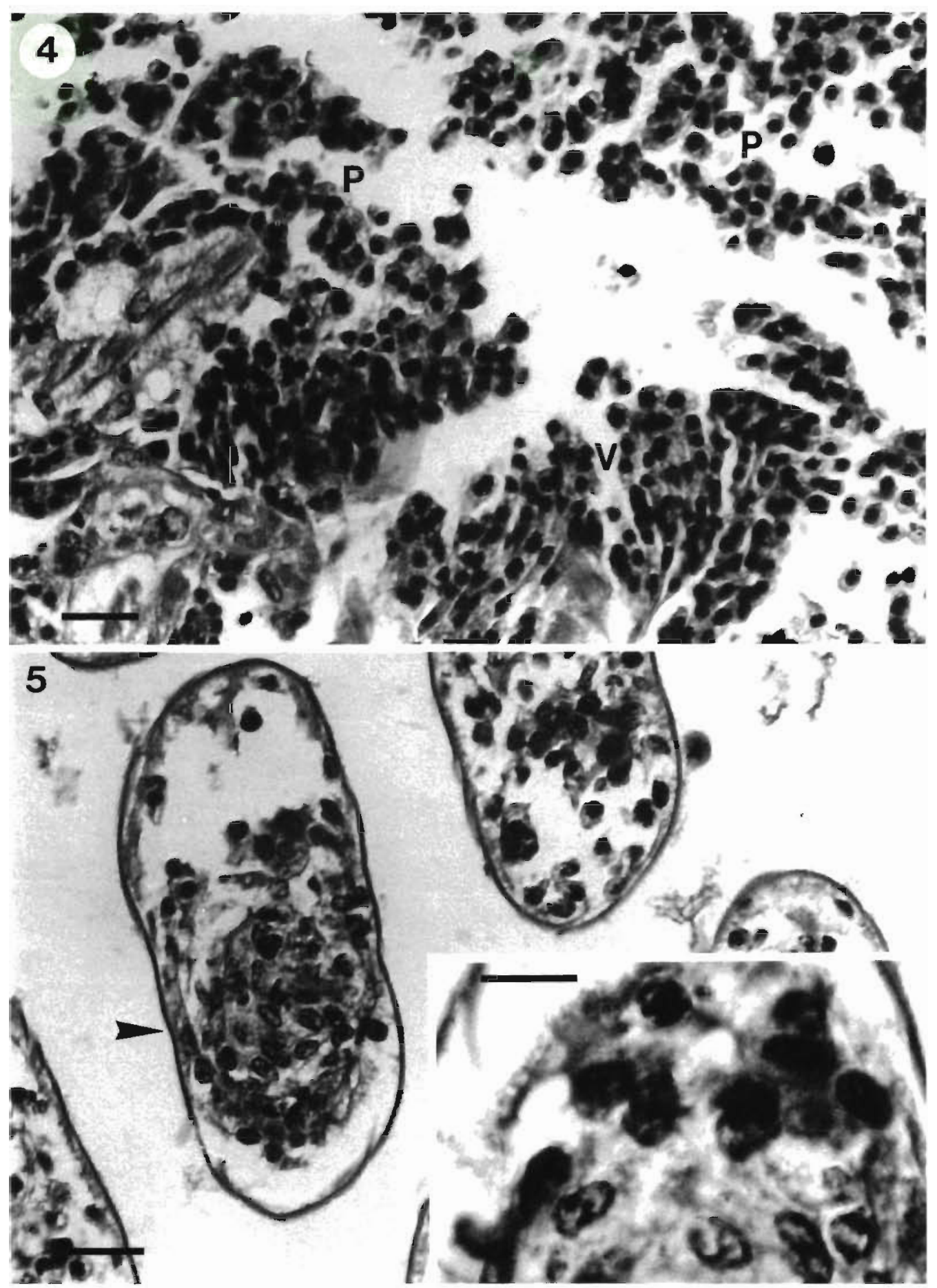

Figs. 4 \& 5. Nephrops norvegicus. Light micrographs of dinoflagellate cells in lobster. Fig. 4. Multinucleate dinoflagellate cell forms within the lumen of the heart. V' 'vermiform' cells; P: 'plasmodial' cells. Scale bar $=20 \mu \mathrm{m}$. Fig. 5. Transverse section of gill filaments showing numerous dinoflagellate cells and aggregation of apparently degenerating host haemocytes (arrow). Scale bar $=20 \mu \mathrm{m}$. Inset: Detail of aggregation of degenerating host haemocytes. Haemotoxylin and Eosin. Scale bar $=10 \mu \mathrm{m}$

haemocoel. The majority of parasite cells were uninucleate, many undergoing mitosis (Fig. 3). These cells typically displayed a weakly-staining reduced cytoplasm surrounding a densely stained nucleus. The mitotic figures revealed the very distinctive ' $V$ '-shaped chromosomes typical of the dinokaryon-type nucleus of dinoflagellates (Cachon \& Cachon 1987). Multi-nucleate 'plasmodial' cells were also common in the haemal spaces (Fig. 4), typically with 2 to 5 nuclei, again often showing mitotic figures. Also present, but apparently 
attached to cardiac muscle within the lumen of the heart, were many multi-nucleate 'vermiform' cells (cf. Newman \& Johnson 1975) (Fig. 4). These also displayed up to 5 nuclei in various mitotic stages.

A major effect of the parasite was the severe distention of the haemocoel and haemal spaces by large numbers of uninucleate and plasmodial forms. This was particularly evident in the heart, haemopoietic tissue, gills and midgut. Distention of the gills was exacerbated by the formation of large aggregations of degenerating host haemocytes (Fig. 5), possibly indicative of an encapsulation reaction in response to the parasite. Although generally there were few haemocytes visible in the haemal spaces, the haemopoietic tissue was both active and enlarged in comparison with that of healthy individuals. Host haemocytes, where present, appeared normal. Damage to host tissues was not widespread, but lysis of hepatopancreatic tubules was evident (Fig. 6), with the tubule cells showing increased vacuolation. Some muscle lysis was also apparent, though this was localised in abdominal musculature with limited invasion of muscle fibre interstices observed in pleopod muscle by both parasite cells and host granulocytes). Large scale infiltration of the haemal spaces and connective tissue of the midgut was accompanied by massive disruption of the muscles of the gut wall (Fig. 7).

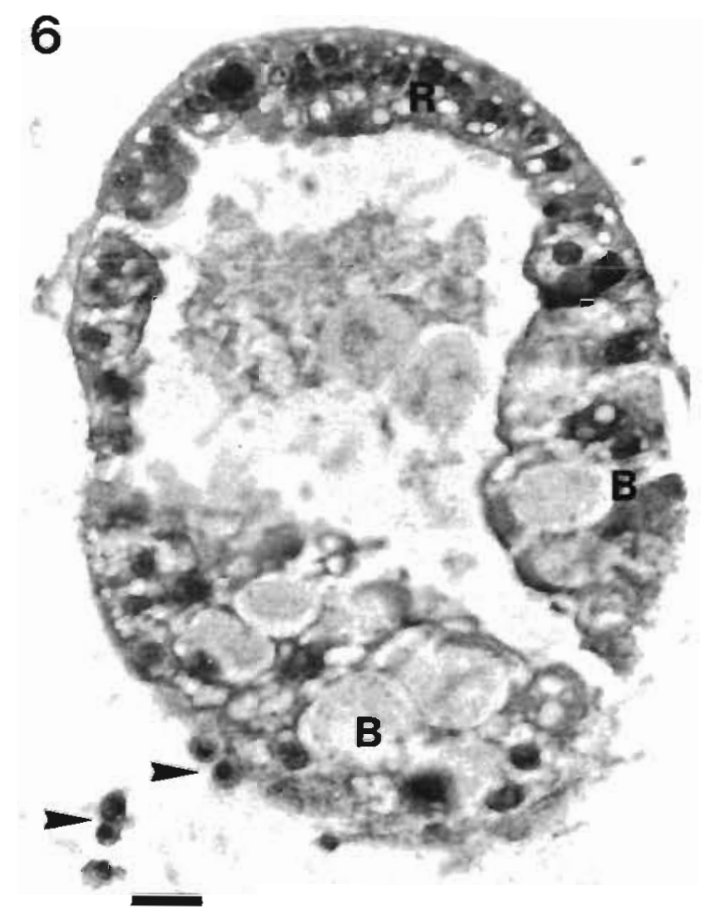

Fig. 6. Nephrops norvegicus. Transverse section of hepatopancreatic tubule showing increased vacuolation of B cells (B) and R cells (R), and dinoflagellate cells in haemal spaces (arrows). Haemotoxylin and Eosin. Scale bar $=20 \mu \mathrm{m}$

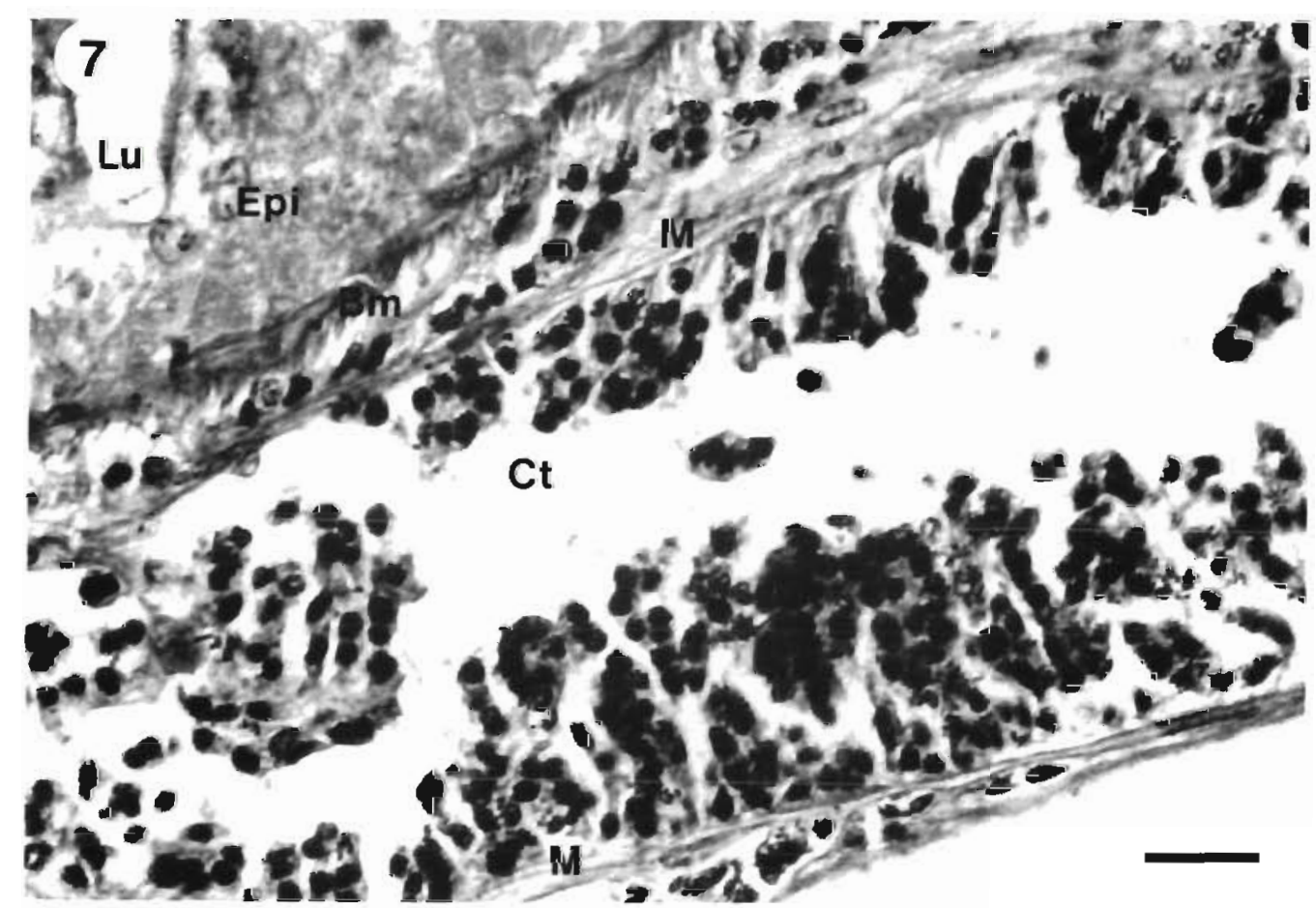

Fig. 7. Nephrops norvegicus, Oblique section of midgut showing invasion of the connective tissues and haemal spaces by parasite cells. Lu: lumen of midgut; Epi: epithelium; $\mathrm{M}$ : muscle; $\mathrm{Ct}$ : connective tissıe layer; Bm: basement membrane Haematoxylin and Eosin. Scale bar $=20 \mu \mathrm{m}$ 


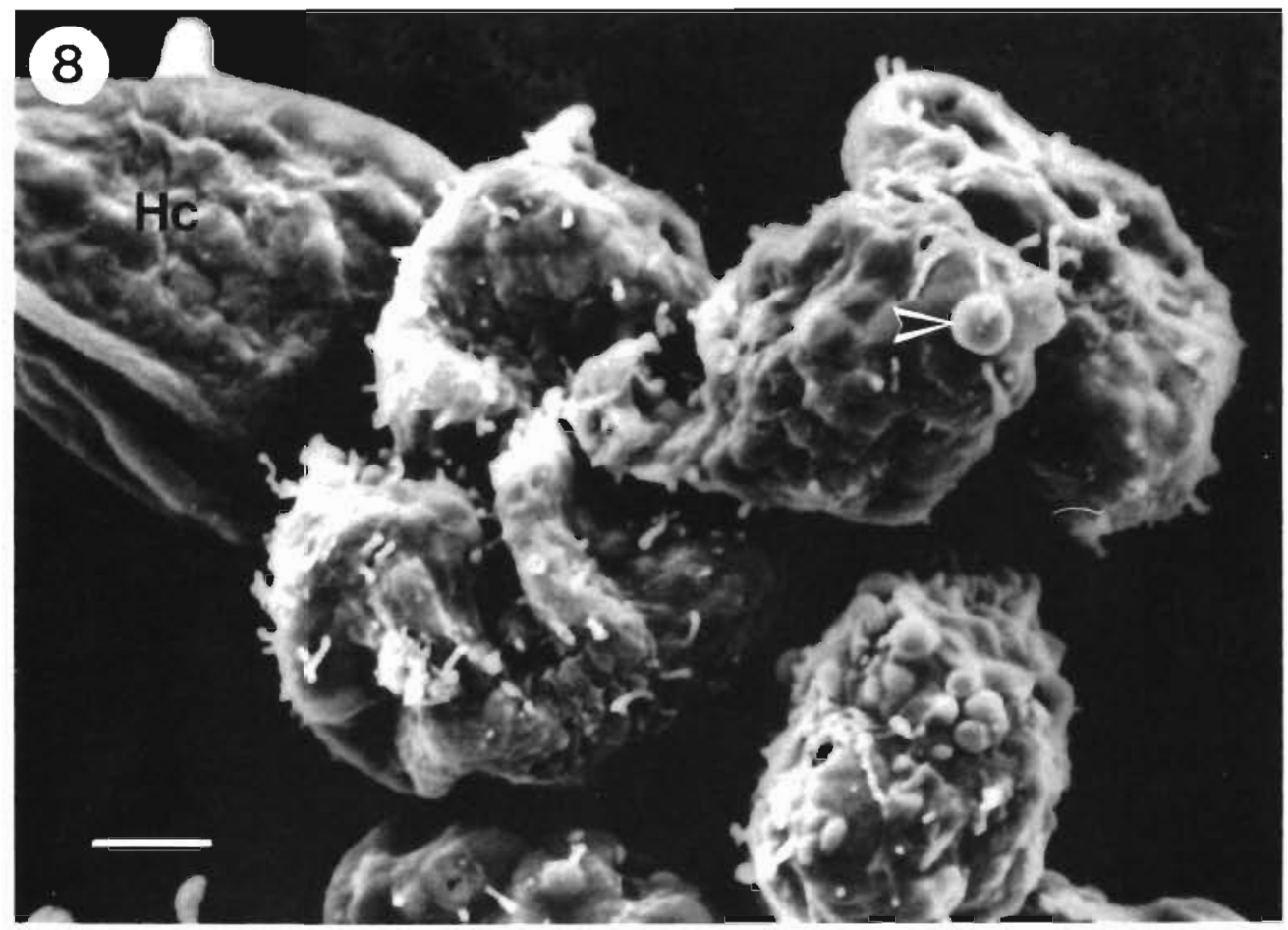

Fig. 8. Nephrops norvegicus. Scanning electron micrograph of dinoflagellate cells in the haemolymph of infected lobster Note irregular cell shape and exudate globules (arrow). Hc : host haemocyte. Scale bar $=2 \mu \mathrm{m}$

\section{Ultrastructure of parasite}

SEM examination of infected haemolymph showed large numbers of irregularly shaped parasite cells similar in size to host haemocytes and without flagella. The cell surface was irregular, showing bulges and extruded material (possibly from trichocysts) similar to that seen by Meyers et al. (1987) in the Bitter Crab Disease parasite (Fig. 8).

TEM observation of the irregularly shaped parasite cells from infected haemolymph showed them to be between 6 and $10 \mu \mathrm{m}$ in diameter and uni- or multinucleate. They were bounded by a characteristic amphiesma, showing amphiesmal alveoli with a 3 membraned structure (Figs. $9 \& 10$ ). There was no indication of thecal plates associated with the amphiesma, nor of microtubules reinforcing the innermost membrane. Nuclei were bounded by a double membrane nuclear envelope and showed chromosomal profiles and nucleoli (Figs. $9 \& 10$ ). The cytoplasm showed large numbers of lipid globules, membranebound inclusion vesicles and many membrane-bound trichocysts. Rough endoplasmic reticulum was present around the trichocysts. The abundant mitochondria showed the tubular cristae characteristic of dinoflagellates (Fig. 10). Chloroplasts were absent, and flagellated stages have not been identified as yet.

The presence of prominent chromosomes and tricho- cysts, a pellicle with amphiesma structure, tubulocristate mitochondria and the absence of chloroplasts and flagella suggest the parasite is the vegetative stage of a parasitic dinoflagellate, probably belonging to the botanical order Syndiniales and possibly related to Hematodinium spp.

\section{Estimates of host mortality}

Table 4 shows the results of survival experiments initiated on 11 March and 8 April 1991, involving (in each case) 50 dinoflagellate-infected Nephrops norvegicus and 51 apparently healthy control lobsters. These experiments were terminated on 7 April and 22 June 1991, respectively. Mortality after 27 and $75 \mathrm{~d}$ was $86 \%$ and $100 \%$ in infected individuals compared with $47 \%$ and $68.6 \%$ in controls, respectively. In both survival experiments, the majority of deaths occurred within the first few days after capture, mortality being greater in infected individuals. No lobsters were observed to recover from infection but, more significantly, none were observed to suffer an increase in severity in condition before death. Also, no lobsters which were healthy upon capture developed the infection under laboratory conditions. The median survival times (in d) of all individuals for which exact times of death were known, showed no significant variation in relation to 


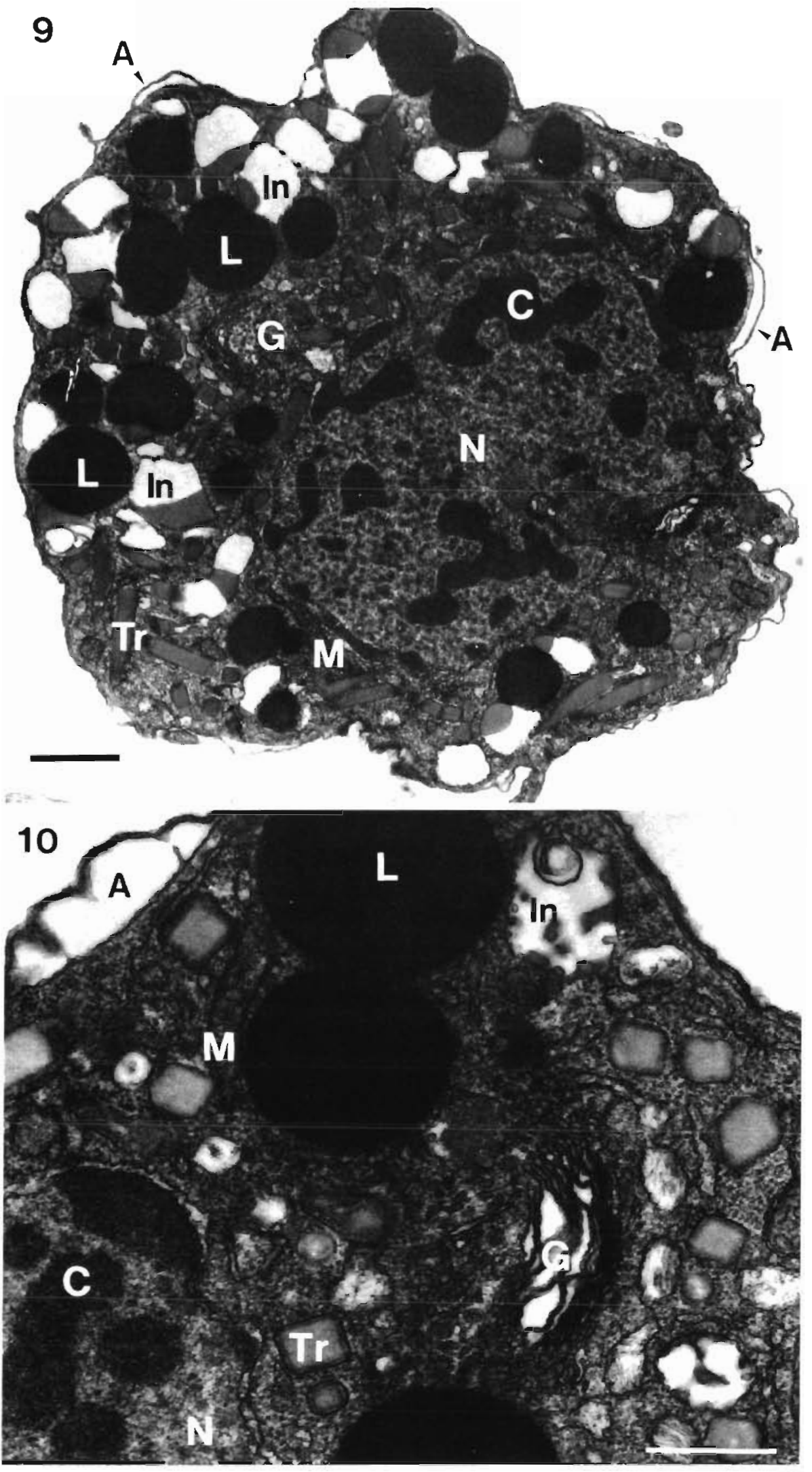

Figs. $9 \&$ 10. Nephrops norvegicus. Transmission electron micrographs of vegetative dinoflagellate cells from infected lobster haemolymph. Fig. 9. Plasmodial cell. Scale bar $=1 \mu \mathrm{m}$. Fig. 10. Detail of cell surface and cytoplasmic inclusions. Scale bar $=0.5 \mathrm{um}$. A: amphiesmal alveolus; $M$ : mitochondrion; $\mathrm{G}$ : golgi apparatus; In: inclusion vesicles: $\mathrm{Tr}$ : trichocysts; L: lipid globules; $N$ : nucleus; $C$ : chromosomal profile 
Table 4. Nephrops norvegicus. Cumulative percent mortality within groups of healthy $(n=51)$ and dinoflagellate-infected ( $n=50$ ) lobsters maintained in the laboratory from (A) 11 March to 7 April, and (B) 8 April to 22 June 1991

\begin{tabular}{|rcccc|}
\hline \multirow{2}{*}{$\begin{array}{c}\text { No. of } \\
\text { days }\end{array}$} & \multicolumn{5}{c}{ Cumulative mortality (\%) } \\
& A & B & A Anfected & B \\
\hline & 0 & 3.9 & 18.0 & 8.0 \\
1 & 3.9 & 3.9 & 28.0 & 10.0 \\
2 & 3.9 & 3.9 & 32.0 & 20.0 \\
3 & 9.8 & 7.8 & 44.0 & 24.0 \\
4 & 19.6 & 11.7 & 52.0 & 26.0 \\
5 & 23.5 & 11.7 & 58.0 & 30.0 \\
6 & 23.5 & - & 60.0 & - \\
7 & - & 13.7 & - & 32.0 \\
8 & - & 13.7 & - & 38.0 \\
9 & - & 13.7 & - & 46.0 \\
10 & 23.5 & - & 66.0 & - \\
11 & 23.5 & 13.7 & 68.0 & 48.0 \\
12 & - & - & - & - \\
- & 23.5 & - & 70.0 & - \\
16 & - & - & - & - \\
- & 23.5 & - & 72.0 & - \\
22 & - & - & - & - \\
- & 47.0 & - & 86.0 & - \\
27 & - & 68.6 & - & 100.0 \\
75 & & & & \\
& & & & \\
\hline
\end{tabular}

Table 5. Nephrops norvegicus. Percent mortality of healthy and dinoflagellate-infected lobsters in relation to severity of infection, assessed by pleopod staging on an arbitrary scale from I to IV (pooled from the 2 survival experiments)

\begin{tabular}{|c|c|c|c|c|c|}
\hline & \multirow{2}{*}{ Healthy } & \multicolumn{4}{|c|}{ Infected } \\
\hline & & I & II & III & IV \\
\hline $\begin{array}{l}\text { No. of ind. included } \\
\text { in experiment }\end{array}$ & 100 & 36 & 31 & 21 & 13 \\
\hline $\begin{array}{l}\text { No. of ind. recorded as } \\
\text { dead at termination of } \\
\text { experiment }\end{array}$ & 21 & 18 & 20 & 14 & 11 \\
\hline$\%$ Mortality & 21.0 & 50.0 & 64.5 & 67.0 & 84.6 \\
\hline
\end{tabular}

severity of infection ( $p>0.5$, Kruskal Wallis 1-way ANOVA). Furthermore, these results indicate that the majority of deaths occurred soon after capture, the median survival time being approximately $4 \mathrm{~d}$. Although survival time showed no variation in relation to severity of infection, percent mortality increased in this respect (Table 5). Mortality in healthy lobsters was $21 \%$ whilst that for infected individuals increased from $50 \%$ for Stage I infection to $84.6 \%$ for Stage IV. (Note that percentage mortalities presented in Table 5 are based only on lobsters for which the exact time of, and condition at, death were known, and are consequently lower than those shown in Table 4).
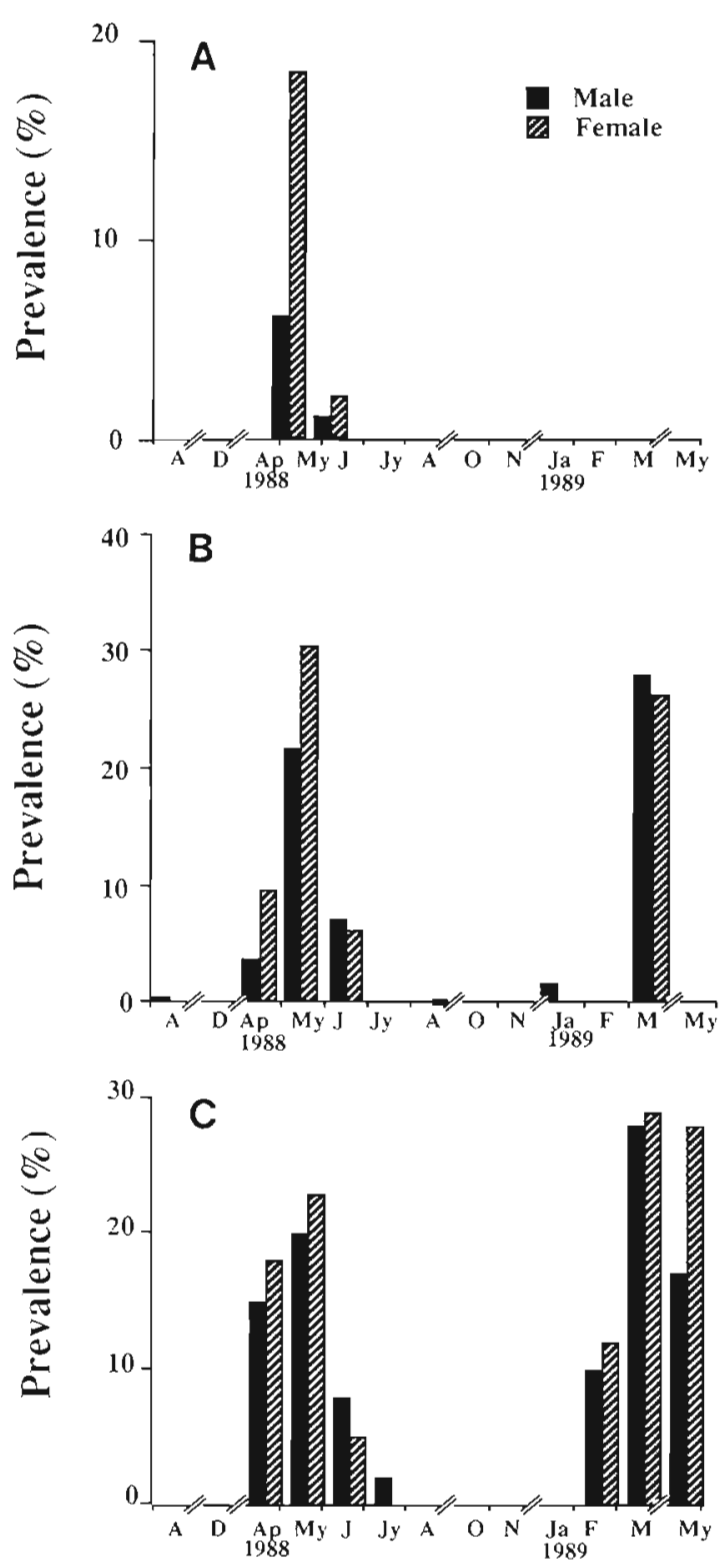

Fig. 11. Nephrops norvegicus. Seasonal variation in the prevalence $(\%)$ of infected lobsters based on small mesh trawl samples takken at 3 locations in 1987-1989: (A) South of Ailsa Craig; (B) North of Arran; (C) Cumbrae-Bute Channel. These sites are labelled 14, 4 and 1 respectively in Fig. 1. Note change in ordinal scale

\section{Distribution and prevalence}

The prevalences of infected Nephrops norvegicus (assessed by body colour alone) in trawl catches from 3 Clyde locations (Fig. 1, Sites 14, 4 and 1) during the period May 1987 to May 1989 are shown in Fig. 11. The prevalence of infection showed a marked seasonal pattern in all 3 locations. Presence of infected lobsters in samples was confined to the period between February 
and June, with evidence of peak numbers occurring in May 1988 and March 1989. At peak times approximately $30 \%$ of trawled $N$. norvegicus taken from the North Arran and Cumbrae Channel sites were affected but there was a lower prevalence of infection at the Ailsa Craig site. Females generally exhibited a higher prevalence of infection than males.

Sampling results in the Clyde and at sites around the west coast of Scotland in 1990 (Fig. 1) are summarised in Table 2. Prevalences of infection were assessed by both body colour and pleopod examination. Pleopod examination generally revealed a higher prevalence of infection because it more readily distinguished less severe cases. Trawl catches in the northern Clyde during early March showed that over $70 \%$ of Nephrops norvegicus were infected, though sample numbers were small, especially for females. Clyde catches in April were also very poor, when the proportion of affected lobsters appeared to have decreased to $20 \%$ in males and $50 \%$ in females. On grounds outside the Firth of Clyde, in the Sound of Jura, Loch Linnhe, and off the Isles of Mull and Rhum, the overall prevalence of infection (14\%) in April was less than that seen in the Clyde.

Examination of pleopods also allowed assessment of disease prevalence in relation to stage in the moult cycle. Infection on Clyde grounds in March was equally prevalent in lobsters in intermoult and those in premoult stages. In April 1990, however, intermoult lobsters taken at sites in the South Minch (except Loch Linnhe) showed higher infection prevalences than premoult individuals taken at the same sites. Dissolved oxygen content, salinity and temperature at all sites were found to be within the normal ranges encountered in these areas.

The results of the sampling programme undertaken in 1991 (Fig. 1) are summarised in Table 3. In early March, approximately half of all trawled Nephrops norvegicus in the northern Clyde grounds showed signs of infection, though sample sizes were small. By 11 to 13 March, and in April, the prevalence of the condition had decreased to around $30 \%$. Again a lower prevalence of infection (16 to $17 \%$ ) was noted on grounds outside the Clyde, in the Sound of Jura and the South Minch. Samples taken in 1991 confirmed the trend indicated by samples in April 1990, showing a significantly higher prevalence of infection in intermoult specimens than in those in premoult, both on Clyde grounds and at other sites around the west coast ( $p<0.05$, Wilcoxon's matched pairs test). Furthermore, as also indicated by 1990 samples, infection was significantly more prevalent ( $p<0.05$, Wilcoxon's matched pairs test) in females than in males, in samples from all west coast grounds in 1991. Further trawl samples taken in May to August, assessed by body colour only,

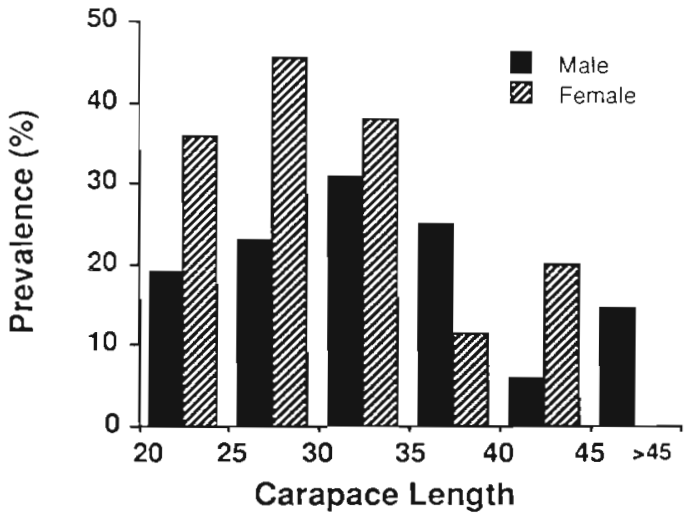

Fig. 12. Nephrops norvegicus. Histogram showing the proportion of infected lobsters in different $5 \mathrm{~mm}$ carapace length size categories. Based on Clyde samples taken in March-April 1991

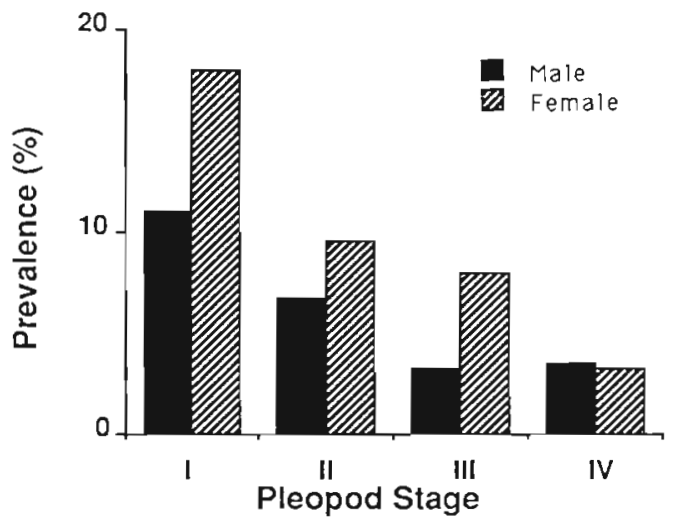

Fig. 13. Nephrops norvegicus. Histogram showing the proportion of infected lobsters in relation to the degree of severity of infection, assessed by pleopod staging on an arbitrary scale from I to IV (see text and Table 1). Specimens were collected from the Firth of Clyde in March and April 1991

not only indicated an increase in the proportion of infected lobsters on grounds close to the Isle of Cumbrae (over $50 \%$ in May and June), but also an apparent extension of the seasonal occurrence of this condition into July (with prevalences as high as $21 \%$ ).

March and April 1991 Clyde samples were further analysed to compare infection levels in differently sized Nephrops norvegicus (Fig. 12) and to provide an assessment of the severity of the disease based upon pleopod stages (Fig. 13). Fig. 12 shows that the infection was most prevalent in individuals of 25 to $35 \mathrm{~mm}$ carapace length. Fig. 13 suggests that the majority of affected $N$. norvegicus sustained light infections during March and April 1991

\section{DISCUSSION}

An infecting organism associated with the diseased condition of Nephrops norvegicus has been identified as a parasitic dinoflagellate, resembling Hematodinium 
perezi Chatton \& Poisson. This identification is based on the characteristic amphiesma structure of the cell surface, the presence of prominent trichocysts, tubular cristae in the mitochondria, and the V-shaped configuration of the large chromosomes (Cachon \& Cachon 1987). The exact identity of the parasite, however, remains uncertain. The gross pathology, the parasite morphology and its effects on the host are similar to those reported in Hematodinium sp. infections of blue crabs Callinectes sapidus (Newman \& Johnson 1975). No flagellate spore stage has thus far been observed, and the 3 distinct forms of apparently vegetative cells seen resemble closely Chatton \& Poisson's (1931) description of Hematodinium. Newman \& Johnson (1975), however, reported the vermiform vegetative cells to be highly motile and free in the haemolymph, whereas these forms were observed only in the heart and haemopoietic tissue of $N$. norvegicus, and were apparently attached to host tissue. The ultrastructure briefly reported for Hematodinium by Newman \& Johnson (1975) was also very similar to that of the dinoflagellate in $N$. norvegicus; differences in nuclear structure (indistinct nucleoli and nuclear membranes in the blue crab parasites) may be the result of processing for TEM.

The histopathological consequences of this disease also bear considerable resemblance to those reported by Meyers et al. (1987) for Bitter Crab Disease (BCD) in Alaskan Tanner crabs Chionoecetes bairdi. Most notable are the disruption of the muscle layers of the midgut wall, the lysis seen in the hepatopancreas, congestion of the gill filaments and muscle lysis. However, the morphology of the causative dinoflagellate of $\mathrm{BCD}$ is distinctly different from that reported here. Meyers et al. (1987) have noted 2 distinct flagellate spore forms with associated trichocysts, and a vegetative form which lacks trichocysts.

Survival experiments revealed higher mortality in infected Nephrops norvegicus, compared with healthy lobsters. Furthermore, mortality increased with increased severity of infection (Table 5). However, the majority of deaths in both infected and control groups occurred soon after capture, which may suggest that mortality was compounded by the additional stress of trawl capture. Median post-capture survival time was constant irrespective of the severity of infection, suggesting that death was not due to infection alone. Nevertheless, it seems likely that this condition causes significant mortalities in $N$. norvegicus, as numbers of deaths were much greater in infected individuals (Table 5). Also, BCD and Hematodinium sp. infections have similar effects on their hosts, and are implicated in causing death. Indeed, blue crabs are known to die from experimental infections of Hematodinium perezi and virtually $100 \%$ mortality occurs in naturally infected Tanner crabs (Meyers 1990)
Death of infected Nephrops norvegicus may be due to many factors, although respiratory dysfunction or disruption of digestion seem most likely. The massive congestive effects of the invading parasite cells, coupled with decreased haemocyanin concentration, probably interfere greatly with gas transport in the haemolymph. Interference with haemocyanin and copper metabolism is also implied by the exaggerated green colouration of the hepatopancreata of infected specimens (suggesting the presence of increased copper concentration within this organ), and the observed low oxygen-carrying capacity of the haemolymph of infected individuals. Abnormal hepatopancreas colouration has also been noted in $N$. norvegicus experiencing abnormal haemocyanin metabolism due to severe hypoxia (Dr. S. P. Baden pers. comm.). Disruption of the midgut and hepatopancreas by the parasite may also affect absorption and digestion, resulting in starvation, even though the lobsters were observed still to be feeding. There is also some evidence of compromised host immuno-competence for although encapsulation reactions by haemocytes were seen, there was a general absence of any cellular defence reaction. A poor host immune response is further supported by several cases of secondary infections by bacteria and ciliate protozoa observed in severely infected $N$. norvegicus, as was observed in heavily infected Tanner crabs (Meyers et al. 1987). Death may also be caused by some form of toxic exudate from the parasite itself. This has been suggested in the case of the causative agent of BCD by Meyers et al. (1987), supported by their observation of exudate droplets adhering to the external surfaces of vegetative parasites. Similar droplets were seen during SEM examination of parasite cells from N. norvegicus haemolymph (Fig. 8).

The most striking similarity between the disease in Nephrops norvegicus and BCD is the high prevalence of infection. Prevalences of Hematodinium sp. infections are generally low, but high levels of infection have been noted in Necora puber and Cancer pagurus (up to $87 \%$ ) in coastal waters of northwest France (Wilhelm \& Boulo 1988, Latrouite et al. 1988). BCD has been reported to infect up to $95 \%$ of Tanner crabs on some grounds, and infection levels as high as $70 \%$ have been seen in $N$. norvegicus. If the infection is fatal, then high levels of infection may have important implications for $N$. norvegicus populations and the fisheries they support. Meyers et al. (1987) reported significant reductions in experimental catch sizes of Tanner crabs associated with high disease prevalence. Also, infections of benthic amphipods by 2 Hematodinium-like dinoflagellates have been implicated in population regulation (Johnson 1986). Furthermore, as in $\mathrm{BCD}$, meat quality of infected $N$. norvegicus is poor which may have consequences for catch mar- 
ketability. At least 1 catch of $N$. norvegicus from the Clyde has been refused at market due to poor meat quality

The occurrence of this condition is markedly seasonal, and coincides with the main annual moulting period of Nephrops norvegicus. The relationship between prevalence of infection and moulting is not at present clear, but is probably important. Similar seasonality and relation to moult cycle have been noted for BCD in Tanner crabs (Meyers et al. 1990, Eaton et al 1991). In $N$. norvegicus there is a difference in the prevalence of infection between lobsters in intermoult and those in premoult, and this may be indicative of increased mortality in infected premoult individuals. The temporal relationship of infection with moulting may reflect the susceptibility of recently moulted individuals to infection, and/or the seasonal production by the parasite of infective stages, possibly as yet unknown spore forms.

The moult-staging technique used is effective in identifying individuals in various stages of premoult, but individuals in postmoult cannot be distinguished from those in intermoult. This means that the high prevalence of infection in samples of intermoult lobsters may have been due mainly to recently moulted postmoult individuals which had been infected shortly after ecdysis. The relationship between infection prevalence and moulting has been suggested by Eaton et al. (1991) as indicative of a possible route of transmission of the causative agent of $\mathrm{BCD}$. Their results indicate that infection prevalence is higher in crabs with newer, softer shells (i.e. more recently moulted), than in those with old shells. The highest prevalences in both old and new shell Tanner crabs occur in summer, shortly after the peak moulting period of the populations concerned. In common with Nephrops norvegicus, this may indicate that more recently moulted individuals are more susceptible to invasion. Such an explanation, however, does not account for the presence of infection in individuals in premoult or with old, hard shells. This situation is seen in both $N$. norvegicus and Chionoecetes bairdi. In addition, the putative transmissive stages of the BCD organism, the spores, are produced too late in the summer to account for the early summer peak of infection by invasion at, or just after, ecdysis (Meyers et al. 1991). It seems likely, therefore, that infection of Tanner crabs occurs through a number of routes, and Meyers et al. (1990) suggest transmission of vegetative stages also. No spore stage has been isolated for Hematodinium, or for the dinoflagellate infecting $N$. norvegicus, and so infection via the gut, or breaches in the cuticle (particularly just after ecdysis, when numerous minor cuticular lesions occur) by vegetative stages may also be possible. The heavy parasitisation of the midgut wall in infections of $N$. norvegicus might implicate this area as a possible site of entry for infective vegetative cells.

Further indications of a link between infection and moulting can be seen in the differences in prevalences of infection between males and females, and the higher prevalences in smaller lobsters. Results of surveys conducted between 1987 and 1991 show a general trend of higher prevalences of infection in females than in males. This difference may be due to differences in moulting times of males and females. Female Nephrops norvegicus moult before males, so that they have soft cuticles to allow mating with hard shell males. In Scottish west coast $N$. norvegicus populations, almost all female moulting occurs in spring, whilst small males moult in late spring to early summer, and larger males in autumn. This means that the majority of females are moulting at the time of peak disease prevalence, whereas fewer males are moulting at this time. The sex difference in prevalence may therefore indicate that infection occurs at, or is greatly facilitated by, moulting. This hypothesis is further supported by the fact that infection is far more prevalent in smaller individuals (of both sexes), since smaller individuals moult more frequently, and only small males moult during the spring moulting period. The implication of moulting in the facilitation of infection may be due not only to the greater ease with which soft postmoult cuticle might be breached by an infective stage, but may also be due to the behavioural changes brought about by moulting. For a short period before, and until the cuticle has hardened after moulting, lobsters remain in their burrows in the sediment and may therefore expose themselves to a greater risk of infection by infective stages liberated into the sediment from the carcasses of diseased individuals

Survey results from 1990 and 1991 suggest that there may be a background level of infection over much of the west coast of Scotland, amounting to about 10 to $15 \%$ of the fishable population. On grounds in the North Clyde Sea Area (Fig. 1, Sites 1 to 4) the proportion of infected lobsters is much higher and appears to have increased in recent years from $30 \%$ in $1988 / 89$ to over $50 \%$ in $1990 / 91$. It must be remembered that these figures are derived from small mesh trawl catches which may not be representative of the Nephrops norvegicus population as a whole. Whether infected individuals are more or less susceptible to capture by trawl is at present unknown.

Clearly much is yet to be learned about the dinoflagellate infecting Nephrops norvegicus. Investigations of morphology, taxonomy, mode of transmission of the parasite, and of its impact on fisheries are continuing in order to assess the current and future impact of a potentially serious pathogen. 
Acknowledgements. The authors thank the following people for their invaluable contributions to this work: Mick Parker and the crew of the RV 'Aora'; June Freel for assistance with haemocyanin measurements; Margaret Mullins for preparation of materials for electron microscopy; Dr S. P. Baden for assistance in collecting survey data: and Dr A. D. Hawkins, Dr A. L. S. Munro and 3 anonymous reviewers for their helpful comments on this manuscript. One of us (R.H.F.) was supported by an SERC CASE Research Studentship with SOAFD, Aberdeen, which is gratefully acknowledged.

\section{LITERATURE CITED}

Aiken, D. E. (1980). Moulting and growth. In: Cobb, J. S., Phillips, B. F. (eds.) The biology and management of lobsters. Vol. 1. Academic Press, New York, p. 91-163

Bridges, C. R., Bicudo, J. E. P. W., Lykkeboe, G. (1979). Oxygen content measurement in blood containing haemocyanin. Comp. Biochem. Physiol. 62A: 457-462

Cachon, J., Cachon, M. (1987). Parasitic dinoflagellates. In: Taylor, F. J. R. (ed.) The biology of Dinoflagellates. Blackwell Scientific Publications, Oxford, p. 571-610

Chatton, E. (1952). Classe des Dinoflagellés ou Péridiniens. In. Grassé. P. P. (ed.) Traité de Zoologie. Vol. 1. Masson, Parıs, p. $309-390$

Chatton, E., Poisson, R. (1931). Sur l'existance, dans le sang des crabs, de peridiniens parasites Hematodinium perezs n.g., n.sp. (Syndinidae). C. R. Seances Soc. Biol. Paris 105: 553-557

Eaton, W. D., Love, D. C., Botelho, C., Meyers, T. R., Imamura, K., Koeneman, T (1991). Preliminary results on the seasonality and life cycle of the parasitic dinoflagellate causing bitter crab disease in Alaskan Tanner crabs (Chionoectes bairdi). J. Invertebr Pathol. 57: 426-434

Johnson, P. T (1980). Histology of the blue crab, Callinectes sapidus. A model for the Decapoda. Praeger, New York

Responsible Subject Editor: J. E. Stewart, Dartmouth, N.S., Canada
Johnson, P. T (1986). Parasites of benthic amphipods: dinoflagellates (Duboscquodinida: Syndinidae). Fish. Bull. U.S. 84: 605-614

Latrouite, D., Morizur, Y., Noël, P., Chagot, D., Wilhelm, G (1988). Mortalité du tourteau Cancer pagurus provoquée par le dinoflagelle parasite: Hematodinium sp. Coun. Meet. int. Counc. Explor Sea C. M. - ICES/K:32

Maclean, S. A., Ruddell, C. L. (1978). Three new crustacean hosts for the parasitic dinoflagellate Hematodinium perezi (Dinoflagellata: Syndinidae). J. Parasitol. 64 - 158-160

Meyers, T R. (1990). Diseases of Crustacea-Diseases caused by protistans and metazoans. In: Kinne, O. (ed.) Diseases of marine animals. Vol. 3. Biologische Anstalt Helgoland, Hamburg, p. 350-400

Meyers, T. R., Botelho, C., Koeneman, T M., Short, S., Imamura, K. (1990). Distribution of bitter crab dinoflagellate syndrome in Southeast Alaskan Tanner crabs, Chionoectes bairdi. Dis. aquat. Org. 9:37-43

Meyers, T R., Koeneman, T M., Botelho, C., Short, S. (1987) Bitter crab disease: a fatal dinoflagellate infection and marketing problem for Alaskan Tanner crabs Chionoectes bairdi. Dis. aquat. Org. 3: 195-216

Newman, M. W., Johnson, C. A. (1975). A disease of blue crabs (Callinectes sapidus) caused by a parasitic dinoflagellate, Hematodinium sp. J. Parasitol. 61: 554-557

Stewart, J. E., Cornick, J. W., Dingle, J. R. (1967). An electronic method for counting lobster (Homarus americanus Milne Edwards) hemocytes and the influence of diet on hemocyte numbers and hemolymph proteins. Can. J. Zool. 45: $291-304$

Tucker, V. A. (1967). Method for oxygen content and dissociation curves on microliter blood samples. J. appl. Physiol. 23: $410-414$

Wilhelm, G., Boulo, V (1988). Infection de l'étrille Liocarcinus puber (L.) par un dinoflagelle parasite de type Hematodinium sp. Counc. Meet. int. Counc. Explor. Sea C.M. - ICES/K:41

Manuscript first received: November 7, 1991

Revised version accepted: February 5, 1992 